\title{
CrimRxiv
}

\section{Who Killed the Berkeley School?Struggles Over Radical Criminology}

Herman Schwendinger, Julia Schwendinger

Published on: Jan 01, 2014

DOI: $10.21428 / c b 6 a b 371.23 a 653 b 3$

License: Creative Commons Attribution 4.0 International License (CC-BY 4.0). 
